\section{制造动物实擥性疾病模型 为針炎研究創造条件}

在大跃进以后，我們开始了針炎机制的研究。除 分析病人針刺前后血和尿液中若干和炎症密切相关成 分的变化外，主要的力量集中在制造动物实驗性疾病 模型，以便用动物研究針炎治妆机制以及針炎实践中 提出的生理学問題。

一、在狗上制造实驗性急性闌尾炎。为了研究針 刺治序急性闌尾炎的机制，要在不切断分布在関尾的 融經及血管与中枢的联系的条件下使闌尾产生炎症。 在过去許多科学工作者的工作中都没有提到这一点， 我們克服了許多困难，終于用在暫时局部缺氧时注射 細菌的办法达到了这个目的。在十五只狗上制造了实 驗性急性闌尾炎，材覌察了件随着炎症发生时血液中 白血球数量、吞㗪能力、谷胱甘肽和粘蛋白含量的变 化。为在动物研究針刺治㡯急性闌尾炎創造了条件。

二、在猴耳制造实驗性压痛点。从耳針疗法的临 床实践中，已經知道当人体某一部分发生病患时，在 耳遊上可以找到压痛点。我們在七只猴制造实驗性骨 折或用化学刺激物刺激神經后，除一只猴外，都可在 耳廓上找到压痛点。关于这类身体某一部分病忠可起 另一远隔部分痛営过敏的現像的形成机制, 所知还很 少。現在在动物身上成功地制造了实驗性耳廓 压痛 点, 就有可能把它放在实驗科学的基础上加以分析。 我們接着文用一般学者訩为可以抑制中枢神桱系統的 脑子网状結构的药物氮普嗎嗪作静脉注射, 結果䒨耳 压痛点不但不減退或消失，反而有压痛反应增强以及 出現新的压痛点的現栠。这一事实为研究压痛点形成 的机制提供了一个綵索。

\section{中国科学院生理研究所}

\section{脑电波分析器試制成功}

为了开展脑电波的研究，我們設計和試制成功一 架脑电波自动分析器。这架分析器可以将人类或动物 四种主要的脑电波 $\theta, \alpha, \beta, r$ 自动进行分析，分別呈 現这四种波中的任何一种波。这样，在研究中郎可以 避集一般通用脑电波記录器所描記的各种电波混清不 清的情况。此外，与英美資本主义国家的机㳦分析法 不同, 这架脑电波分析器是完全技照大脑交流电波本 身的特点設計的，它整体地、而不是孤立地分析出 $\theta$
波(每秒 4 至 7 次)、 $\alpha$ 波(每秒 8 至 13 次)、 $\beta$ 波(每 秒 14 至 28 次) 及 $r$ 波 (每秒 30 次至 55 次) 等四种大 脑主要交流电波，这有利于对这四种电波相互閒的比 較研究。为适应研究工作上的需要, 这架仪器在綫路 結构上也有自己的若干特点。

\section{中国科学院心理呼究所}

\section{关于䣙連山的研究}

侕連山位于我国西北部，跨越甘、靑两省，它是 巨大的中亚高原的一个重要的組成部分。东西长約 $800 \sim 1000$ 公里，南北寛 300 500 公里，由一系列互 相平行的山脉和谷地組成，山区內部的高度，一般海 拔在 3000 米以上，最高山等 (疏勒面山) 达 6300 米。

解放以前，这一巨大的山䒺无論在地质上和地理 上都基本上是宾白地区。解放以后，随着国家对內地 开发和建設工作的发展，需要在西北区找出大量的各 种矿产資源。因而在祁連山曾唭开了較大規模的普查 勘探工作。但是，剠連山地区十分辽閵，地稹构造复 杂，因而极需要对它来进行較采統的区域地稹特点和 成研”规律的研究，同时对䢵連山进行棕合地稹研究， 还有着重大的学术意义，可以补正我国过去对西部地 槽地区研究的不足，从而比較全面地了解我国一个地 槽区地盾发育的历史。

中国科学院地稹研究所基于以上的䛋識, 組織了 一支部連山地稹队，要求在四年之內(1956年开始)， 通过地层、岩石、构造、矿床等方面的綜 合 調 查研 究，初步明动連山区域地稹特点、地质发展历史和 矿产分布规律，編制出成矿㑔測图。最后出版总結性 的邢連山地稹志，以便从理論上提出矿休勘探各方面 的意見。

經过 1956 1958 年野外队工作及 1959 年室內整 理工作，基本上已經完成了这一任务。1956年在苏联 专家 B. M. 西尼村数授的帮助与指导下，共穿越了十 一条路綫，对郃連山区有了一个概略的了解。1957年 采用了以专題研究为主，以路綫为輔的研究方針，結 果使我們有了一些較全面的訩識。1958年夏天，經过 伟大的整风运动，全民掀起了大跃进的高潮，我所又 提出了科学研究与找矿相結合的方針，結果既找到了 矿，又提高了研究理論水平，也培养了干部，而且多 快好省地提前一年完成了任务。

三年来，总的来說，我們基本上搞清了䄮連山区 地稹、构造、岩装活动、地盾发展历史及成矿规律。 这些研究成果将以埅連山地稹志的形式先后出版。現 